\title{
Hubungan Pendidikan dan Pengetahuan Ibu, Dukungan Keluarga, dan Faktor Budaya Terhadap Pemberian ASI Parsial
}

\author{
Sarastya Ambarsari, Moch. Yunus*, Anindya Hapsari \\ Universitas Negeri Malang, Jl. Semarang No. 5 Malang, Jawa Timur, Indonesia \\ *Penulis korespondensi, Surel: moch.yunus.fik@um.ac.id
}

Paper received: 31-9-2021; revised: 14-9-2021; accepted: 21-9-2021

\begin{abstract}
Partial breast milk is breast milk and other foods other than breast milk that are given when the baby is under six months old with continuous feeding or when the baby is born, such as formula milk, porridge, and other complementary foods (prelacteal food). The study aims to determine the connection between education and knowledge of mothers, family support, and culture on partial breastfeeding. This research utilize a cross sectional research methodology and was an analytic observational study. In January until February 2021, data was collected. The sample during this study was 43 respondents. Purposive sampling methodology for victimization sampling. During this study, questionnaire and interview were used as the instrument and the info analysis employed in this study was Spearman rho. The results demonstrated that, the education, family support, and cultural factor variables have no relationship with partial breastfeeding with a p-value of 0,134, 0,091, and 0,934 . Meanwhile, the knowledge variable has a relationship with partial breastfeeding with a pvalue of 0,033 . The conclusion obtained is that there is no significant relationship between mother's education, family support, and culture on partial breastfeeding, but there is a significant relationship between the knowledge of partial breastfeeding.
\end{abstract}

Keywords: education; knowledge; family support; cultural factors; partial breastfeeding

\begin{abstract}
Abstrak
Air susu ibu parsial adalah ASI dan makanan lain selain ASI yang diberikan pada saat bayi berusia dibawah enam bulan diberikan secara kontinyu atau saat bayi baru lahir seperti susu formula, bubur, serta makanan tambahan lainnya (makanan prelakteal). Ibu memberikan ASI parsial disebabkan oleh banyak faktor, yaitu pendidikan ibu, pengetahuan ibu, dukungan keluarga, serta faktor budaya. Penelitian bertujuan untuk mengetahui hubungan antara pendidikan dan pengetahuan ibu, dukungan keluarga, serta faktor budaya terhadap pemberian ASI parsial. Penelitian ini merupakan penelitian observasional analitik dengan desain cross sectional. Pengumpulan data dijalankan pada bulan Januari-Februari 2021. Populasi penelitian ini adalah ibu yang memiliki bayi berusia 6-12 bulan dengan jumlah sampel sebanyak 43 responden. Pengumpulan sampel pada penelitian dengan metode purposive sampling. Instrumen dalam penelitian menggunakan kuesioner dan wawancara serta analisis data menggunakan Spearman rho. Hasil penelitian membuktikan bahwa, variabel pendidikan, dukungan keluarga, dan faktor budaya tidak terdapat hubungan signifikan terhadap pemberian ASI parsial dengan p-value yaitu 0,134, 0,091, dan 0,934. Sedangkan, variabel pengetahuan memiliki hubungan signifikan dengan pemberian ASI parsial dimana $p$-value adalah 0,033 . Diperoleh kesimpulan yaitu tidak ada hubungan signifikan antara pendidikan ibu, dukungan keluarga, dan faktor budaya terhadap pemberian ASI parsial, namun terdapat hubungan signifikan antara pengetahuan ibu terhadap pemberian ASI parsial.
\end{abstract}

Kata kunci: pendidikan; pengetahuan; dukungan keluarga; faktor budaya; ASI parsial

\section{Pendahuluan}

Air susu ibu (ASI) adalah hasil yang dikeluarkan oleh tubuh dalam kelenjar payudara ibu yang berbentuk cairan. Air susu ibu (ASI) eksklusif adalah suatu cairan berupa susu yang 
dikeluarkan oleh ibu kepada bayinya saat bayi tersebut baru lahir sampai dengan berusia enam bulan dimana ASI tersebut menjadi makanan pokok bagi bayi yang belum ditambahkan atau digantikan dengan makanan atau minuman lain selain ASI. ASI parsial yaitu mengacu pada diberikannya ASI pada bayi dan makanan lain selain ASI yang diberikan pada saat bayi berusia dibawah enam bulan dengan pemberian secara kontinyu atau diberikan saat bayi baru lahir seperti susu buatan atau formula, bubur beras, serta makanan tambahan lainnya (makanan prelakteal) (Kementerian Kesehatan RI Badan Penelitian dan Pengembangan, 2018).

Menurut data dari Riskesdas Provinsi Jawa Timur pada tahun 2018 didapatkan hanya sebanyak 40,05\% proporsi pemberian ASI eksklusif, sebanyak 12,01\% pemberian ASI parsial, dan sebanyak 1,45\% yang termasuk dalam pola pemberian ASI predominan (Kementerian Kesehatan Republik Indonesia Provinsi Jawa Timur, 2018). Terdapat persentase data menyusui parsial menurut kelompok umur yaitu sebanyak 55,1\% pada kelompok umur 0 bulan, sebanyak 63,1\% pada kelompok umur 1 bulan, sebanyak 65,2\% pada kelompok umur 2 bulan, sebanyak 70,4\% pada kelompok umur 3 bulan, sebanyak 70,7\% pada kelompok umur 4 bulan, dan sebanyak 83,2\% yang memberikan ASI parsial pada kelompok umur 5 bulan (Kemenkes RI. Pusat Data dan Informasi Situasi dan Analisis ASI Eksklusif, 2014).

Bayi dengan pemberian ASI parsial lebih rentan terhadap infeksi sehingga akan berpeluang lebih tinggi mengalami infeksi dibanding bayi dengan pola menyusui eksklusif dan predominan (Putri \& Illahi, 2017). Bayi yang telah diberikan makanan sebelum 6 bulan akan lebih rentan dengan kejadian infeksi karena enzim-enzim yang diperlukan untuk mencerna makanan pada organ pencernaan yang masih belum sempurna. Selain itu, bayi dengan pemberian ASI parsial akan mengakibatkan gangguan terhadap pertumbuhan berat bayi karena kebutuhan asupan nutrisi bayi yang tidak terpenuhi dengan baik (Putri \& Illahi, 2017).

Bayi yang diberikan makanan terlalu dini dan diberikan susu formula kurang dari usia 4 bulan akan menyebabkan faktor risiko diabetes tipe 1. Penelitian yang telah dilakukan menunjukkan bahwa pemberian ASI eksklusif yang terlalu pendek dan waktu awal pemberian susu formula secara signifikan berhubungan dengan risiko diabetes tipe 1. Selain itu, pemberian susu formula dan pemberian makanan padat pada bayi yang terlalu dini (kurang dari 4 bulan) akan menyebabkan peradangan mukosa dan meningkatkan permeabilitas usus. Peradangan terjadi akibat dari konsekuensi diabetes yang tidak dapat dikesampingkan (Virtanen, dkk., 2013).

Diberikannya ASI parsial oleh ibu dapat dipengaruhi oleh beberapa faktor, yaitu pendidikan ibu. Pendidikan dijelaskan sebagai suatu bentuk usaha yang secara sadar dan terencana bagi peserta didik dalam menciptakan suasana dalam proses pembelajaran agar dapat mengembangkan diri yaitu keagamaan, pengendalian diri, kecerdasan, keterampilan, akhlak mulia, dan kepribadian (Mardhani, 2019). Hasil penelitian yang sudah dijalankan oleh Rosita \& Imrohwati (2016) dengan judul "Hubungan Tingkat Pendidikan Ibu dengan Pemberian ASI parsial pada Bayi Usia 0-6 Bulan" membuktikan bahwa ada hubungan bermakna pada pemberian ASI parsial dengan tingkat pendidikan ibu (Rosita \& Imrohwat, 2016). Faktor penyebab lain dilakukannya pemberian ASI parsial adalah pengetahuan yang dimiliki oleh ibu. Pengetahuan adalah tahu (know) dan aplikasi (application) dimana proses mengingat kembali dan menerapkan materi dari yang telah dipelajari atau diterima dari situasi tertentu (Widiyoga, dkk., 2020). Hasil penelitian yang sudah dijalankan oleh Yanthi dan Masruroh (2018) mengenai hubungan pengetahuan dan pekerjaan ibu dengan pemberian ASI 
parsial di Desa Ngampin wilayah kerja Puskesmas Ambarawa, didapatkan hasil bahwa ada hubungan bermakna antara tingkat pengetahuan yang dimiliki oleh ibu dengan pemberian ASI parsial (Yanthi \& Masruroh, 2018). Selain faktor pendidikan dan pengetahuan, terdapat juga faktor budaya yang mendorong ibu untuk memberikan ASI parsial. Hasil penelitian yang telah dilakukan oleh Arsyati dan Rahayu (2019) menjelaskan bahwa hampir seluruh responden ibu memberikan madu atau air gula asam kepada bayi sejak bayi tersebut masih neonatus karena dapat membuang kotoran selama bayi masih dalam kandungan (Arsyati \& Rahayu, 2019). Beberapa faktor lain yang menyebabkan ibu memberikan ASI parsial adalah yaitu dukungan keluarga. Penelitian yang dilakukan oleh Winona dan Sari (2016) mengenai diberikannya ASI parsial yang berada pada BPMN Jakarta Selatan menunjukkan bahwa dengan tidak adanya dukungan keluarga mempunyai resiko 7,5 kali dalam melakukan pemberian ASI parsial dibandingkan dengan adanya dukungan keluarga yang diterima oleh responden (Winona \& Sari, 2016).

Menurut hasil data berdasarkan Profil Kesehatan Indonesia tahun 2019, rata-rata yang memberikan ASI eksklusif di Provinsi Jawa Timur sebanyak 78,27\% (Kementerian Kesehatan Republik Indonesia, 2019). Hal tersebut masih belum memenuhi target nasional sebesar $80 \%$. Berdasarkan data dari Profil Kesehatan Provinsi Jawa Timur, rata-rata pemberian ASI eksklusif di Kota Malang sebanyak 81,4\% (Dinas Kesehatan Provinsi Jawa Timur, 2020). Sedangkan, jika dilihat berdasarkan data dari Dinas Kesehatan Kota Malang, rata-rata yang memberikan ASI eksklusif dari 16 Puskesmas di Kota Malang pada tahun 2017, 2018, dan 2019 secara berurutan adalah $80,5 \%, 80,5 \%$, dan 82,2\%. Hal ini sudah memenuhi target nasional sebesar 80\% (Sihombing, 2018). Sedangkan yang terbukti, terdapat beberapa Puskesmas yang masih belum memenuhi target dari pemerintah. Rata-rata cakupan ASI eksklusif selama 3 tahun terakhir yang terendah adalah Puskesmas Cisadea dengan rata-rata sebesar 67,2\%, Puskesmas Mojolangu dan Ciptomulyo dengan masing-masing sebesar 71,6\%, dan Puskesmas Arjowinangun sebesar 73,9\%. Pada tahun 2019, terdapat penurunan cakupan pemberian ASI eksklusif yang cukup jauh di Puskesmas Arjowinangun yang sebelumnya mengalami peningkatan dari tahun 2017 sampai 2018 yaitu dari 81,5\% sampai 80,2\%, lalu menurun dari tahun 2018 sampai 2019 yaitu dari 80,2\% menjadi 59,9\%. Dari data tersebut menunjukkan bahwa terdapat cukup banyak bayi yang tidak menerima ASI secara eksklusif yang diberikan oleh ibunya serta mungkin saja, bayi yang tidak menerima ASI secara eksklusif telah diberikan makanan serta minuman buatan atau tambahan lainnya berupa ASI parsial dan bahkan tidak diberikan ASI sama sekali.

Berdasarkan paparan yang telah peneliti jelaskan tersebut diatas, maka peneliti berminat dalam menjalankan penelitian mengenai beberapa faktor yang berkaitan oleh diberikannya ASI parsial dengan variabel tingkat pendidikan ibu, tingkat pengetahuan ibu, dukungan keluarga, serta faktor budaya dengan judul penelitian, yaitu "Hubungan antara Pendidikan dan Pengetahuan Ibu, Dukungan Keluarga, dan Faktor Budaya terhadap Pemberian ASI Parsial".

\section{Metode}

Penelitian ini termasuk dalam observasional analitik yang menggunakan desain cross sectional. Variabel yang digunakan dalam penelitian yaitu pendidikan ibu, pengetahuan ibu, dukungan keluarga, dan faktor budaya (independent variable) dan ASI parsial (dependent variable). Penelitian ini sudah memperoleh laik etik dari Komisi Etik Penelitian Kesehatan Politeknik Kesehatan Kemenkes Malang dengan nomor 039. Pengumpulan data dijalankan 
pada bulan Januari-Februari 2021. Populasi yang digunakan dalam penelitian ini yaitu ibu yang memiliki bayi berusia 6-12 bulan dan bertempat tinggal di wilayah kerja Puskesmas Arjowinangun, Kecamatan Kedungkandang, Kota Malang. Berdasarkan hasil perhitungan sampel, sampel pada penelitian ini diperoleh sebanyak 39 responden, namun untuk meminimalisir kesalahan hasil data maka ditambahkan $10 \%$ sampel dari jumlah sampel minimum sehingga jumlah sampel menjadi 43 responden. Pengumpulan sampel yang dilaksanakan pada penelitian ini yaitu dengan metode purposive sampling. Instrumen atau alat dalam penelitian menggunakan kuesioner dan wawancara. Analisis data pada penelitian ini menggunakan Spearman rho.

\section{Hasil dan Pembahasan}

\subsection{Hasil}

Tabel 1. Distribusi Frekuensi Berdasarkan Usia Bayi

\begin{tabular}{cccc}
\hline Variabel & Kategori (Bulan) & \multicolumn{2}{c}{ Jumlah } \\
\cline { 3 - 4 } & & f & Persentase (\%) \\
\hline \multirow{4}{*}{ Umur } & 6 & 6 & 14 \\
& 7 & 5 & 11,6 \\
& 8 & 3 & 7 \\
& 9 & 8 & 18,6 \\
& 10 & 6 & 14 \\
& 11 & 6 & 14 \\
& 12 & 9 & 20,9 \\
\hline
\end{tabular}

Menurut tabel 1 diketahui bahwa jumlah seluruh usia bayi adalah 43 bayi (100\%). Usia bayi paling banyak berada pada usia 12 bulan sebanyak 9 bayi dengan persentase 20,9\%. Sedangkan, usia bayi paling sedikit berada pada usia 8 bulan sebanyak 3 bayi dengan persentase $7 \%$.

Tabel 2. Distribusi Frekuensi ASI Parsial

\begin{tabular}{llcc}
\hline \multirow{2}{*}{ Variabel } & \multirow{2}{*}{ Kategori } & \multicolumn{2}{c}{ Jumlah } \\
\cline { 3 - 4 } & & f & Persentase (\%) \\
\hline \multirow{2}{*}{ ASI Parsial } & Ya & 28 & 65,1 \\
& Tidak & 15 & 34,9 \\
\hline Total & & 43 & 100 \\
\hline
\end{tabular}

Menurut tabel 2 didapatkan hasil bahwa responden memberikan ASI parsial kepada bayinya sebanyak 28 responden $(65,1 \%)$ serta yang tidak melakukan pemberian ASI parsial kepada bayinya sebanyak 15 responden $(34,9 \%)$. 
Tabel 3. Distribusi Frekuensi Tingkat Pendidikan Ibu

\begin{tabular}{llcc}
\hline \multirow{2}{*}{ Variabel } & \multirow{2}{*}{ Kategori } & \multicolumn{2}{c}{ Jumlah } \\
\cline { 3 - 4 } & & f & Persentase (\%) \\
\hline \multirow{3}{*}{ Pendidikan } & Tinggi & 6 & 14 \\
& Sedang & 17 & 39,5 \\
& Rendah & 20 & 46,5 \\
\hline Total & & 43 & 100 \\
\hline
\end{tabular}

Menurut tabel 3 terlihat bahwa responden yang memiliki pendidikan tinggi sebanyak 6 responden (14\%). Responden yang memiliki pendidikan sedang sebanyak 17 responden $(39,5 \%)$ dan responden terbanyak berada pada pendidikan rendah sebanyak 20 responden $(46,5 \%)$.

Tabel 4. Distribusi Frekuensi Tingkat Pengetahuan Ibu

\begin{tabular}{llcc}
\hline \multirow{2}{*}{ Variabel } & \multirow{2}{*}{ Kategori } & \multicolumn{2}{c}{ Jumlah } \\
\cline { 3 - 4 } & & f & Persentase (\%) \\
\hline \multirow{3}{*}{ Pengetahuan } & Baik & 24 & 55,8 \\
& Cukup & 16 & 37,2 \\
& Rendah & 3 & 7 \\
\hline Total & & 43 & 100 \\
\hline
\end{tabular}

Menurut tabel 4, terlihat bahwa dari 43 responden diperoleh hasil sebanyak 24 responden (24\%) dengan tingkat pengetahuan baik, sebanyak 16 (37,2\%) respondenyang memiliki pengetahuan cukup, dan sebanyak 3 responden (7\%) dengan tingkat pengetahuan rendah.

Tabel 5. Distribusi Frekuensi Dukungan Keluarga

\begin{tabular}{llcc}
\hline \multirow{2}{*}{ Variabel } & \multirow{2}{*}{ Kategori } & \multicolumn{2}{c}{ Jumlah } \\
\cline { 3 - 4 } & & f & Persentase (\%) \\
\hline Dukungan Keluarga & Mendukung & 22 & 51,2 \\
& Tidak Mendukung & 21 & 48,8 \\
\hline Total & & 43 & 100 \\
\hline
\end{tabular}

Menurut tabel 5 terlihat bahwa dari 43 responden terdapat 22 responden (51,2\%) yang mendapat dukungan dari keluarga dan 21 responden (48,8\%) yang tidak mendapat dukungan dari anggota keluarga.

Tabel 6. Distribusi Frekuensi Faktor Budaya

\begin{tabular}{llcc}
\hline \multirow{2}{*}{ Variabel } & \multirow{2}{*}{ Kategori } & \multicolumn{2}{c}{ Jumlah } \\
\cline { 2 - 4 } & & $\mathbf{f}$ & Persentase (\%) \\
\hline Faktor Budaya & Mengikuti & 37 & 86 \\
\cline { 2 - 4 } & Tidak Mengikuti & 6 & 14 \\
\hline Total & & 43 & 100 \\
\hline
\end{tabular}


Menurut tabel 6, terlihat bahwa dari 43 responden diperoleh hasil bahwa responden dengan faktor budaya mengikuti adalah sebanyak 37 responden (86\%) serta responden dengan faktor budaya yang tidak mengikuti sebanyak 6 responden (14\%).

Analisis bivariat dilakukan dengan uji Spearman rho untuk mengetahui hubungan antara tingkat pendidikan dengan pemberian ASI parsial. Pengujian analisis tersebut ditunjukkan dalam tabel 7 adalah sebagai berikut:

Tabel 7. Hubungan Pendidikan terhadap Pemberian ASI Parsial

\begin{tabular}{lcccc}
\hline \multirow{2}{*}{ Pendidikan } & \multicolumn{2}{c}{ ASI Parsial } & Total & p-value \\
& Ya & Tidak & & \\
\hline Tinggi (Perguruan Tinggi) & 4 & 2 & 6 & \\
& $66,7 \%$ & $33,3 \%$ & $100 \%$ & \\
Sedang (SMA/SMK) & 8 & 9 & 17 & \\
\multirow{2}{*}{ Rendah (SD-SMP/MTs) } & $47,1 \%$ & $52,9 \%$ & $100 \%$ & 0,134 \\
\multirow{2}{*}{ Total } & 16 & 4 & 20 & \\
& $80 \%$ & $20 \%$ & $100 \%$ & \\
\hline
\end{tabular}

Menurut tabel 7, didapat bahwa dari 43 responden yang berpendidikan tinggi dengan melakukan pemberian ASI parsial adalah 4 responden $(66,7 \%)$, sedangkan yang tidak melakukan pemberian ASI parsial sebanyak 2 responden (33,3\%). Responden dengan pendidikan sedang dan memberikan ASI parsial sebanyak 8 responden $(47,1 \%)$ dan yang tidak memberikan ASI parsial sebanyak 9 responden $(52,9 \%)$. Responden yang berpendidikan rendah serta melakukan pemberian ASI parsial adalah 16 responden (80\%) dan yang tidak memberikan ASI parsial sebanyak 4 responden (20\%).

Menurut hasil yang diperoleh dengan uji statistik Spearman Rho membuktikan nilai signifikansi $p$-value sebesar 0,134 dimana derajat kemaknaan yang digunakan adalah $\alpha<0,05$ $(p$-value $>0,05)$. Hal ini menunjukkan bahwa hipotesis nol diterima. Sehingga, diperoleh kesimpulan bahwa tidak ada hubungan yang signifikan antara pendidikan terhadap pemberian ASI parsial.

Tabel 8. Hubungan Pengetahuan terhadap Pemberian ASI Parsial

\begin{tabular}{lcccc}
\hline \multirow{1}{*}{ Pengetahuan } & \multicolumn{2}{c}{ ASI Parsial } & Total & p-value \\
& Ya & Tidak & & \\
\hline Baik (skor 76-100\%) & 12 & 12 & 24 & \\
& $50,0 \%$ & $50,0 \%$ & $100 \%$ & \\
Cukup (skor 56-75\%) & 14 & 2 & 16 & \\
& $87,5 \%$ & $12,5 \%$ & $100 \%$ & 0,033 \\
Kurang (skor <56\%) & 2 & 1 & 3 & \\
Total & $66,7 \%$ & $33,3 \%$ & $100 \%$ & \\
& 28 & 15 & 43 & \\
\hline
\end{tabular}

Berdasarkan tabel 8, diperoleh hasil dari 43 responden yang berpengetahuan baik dan yang melakukan pemberian ASI parsial maupun tidak memberikan ASI parsial sebanyak 12 
responden (50\%). Responden yang berpengetahuan cukup dan memberikan ASI parsial adalah 14 responden (87,5\%) serta tidak memberikan ASI parsial adalah 2 responden (12,5\%). Responden yang berpengetahuan rendah serta memberikan ASI parsial adalah 2 responden $(66,7 \%)$ dan tidak memberikan ASI parsial adalah 1 responden $(33,3 \%)$.

Berdasarkan hasil uji statistik Spearman Rho yang diperoleh, membuktikan nilai signifikansi $p$-value adalah 0,033 dimana tingkat signifikansi yang digunakan adalah $\alpha<0,05$ $(p$-value $<0,05)$. Hal ini membuktikan bahwa hipotesis nol ditolak. Dengan demikian, diperoleh kesimpulan bahwa ada hubungan yang signifikan antara tingkat pengetahuan terhadap pemberian ASI parsial.

Tabel 9. Hubungan Dukungan Keluarga terhadap Pemberian ASI Parsial

\begin{tabular}{|c|c|c|c|c|}
\hline \multirow[t]{2}{*}{ Dukungan Keluarga } & \multicolumn{2}{|c|}{ ASI Parsial } & \multirow{2}{*}{ Total } & \multirow{2}{*}{$p$-value } \\
\hline & Ya & Tidak & & \\
\hline \multirow{2}{*}{ Mendukung } & 17 & 5 & 22 & \multirow{6}{*}{0,091} \\
\hline & $77,3 \%$ & $22,7 \%$ & $100 \%$ & \\
\hline \multirow[t]{2}{*}{ Tidak Mendukung } & 11 & 10 & 21 & \\
\hline & $52,4 \%$ & $47,6 \%$ & $100 \%$ & \\
\hline \multirow[t]{2}{*}{ Total } & 28 & 15 & 43 & \\
\hline & $65,1 \%$ & $34,9 \%$ & $100 \%$ & \\
\hline
\end{tabular}

Berdasarkan tabel 9, diperoleh hasil dari 43 responden yang mendapat dukungan keluarga dengan pemberian ASI parsial sebanyak 17 responden (77,3\%) serta tidak melakukan pemberian ASI parsial sebanyak 5 responden (22,7\%). Responden yang tidak memberikan dukungan keluarga dengan pemberian ASI parsial adalah 11 responden $(52,4 \%)$ serta tidak melakukan pemberian ASI parsial adalah 10 responden $(47,6 \%)$.

Berdasarkan hasil yang diperoleh dengan uji statistik Spearman rho membuktikan nilai signifikansi $p$-value adalah 0,091 dimana derajat kemaknaan yang digunakan adalah $\alpha<0,05$ ( $p$-value < 0,05). Hal ini menunjukkan bahwa hipotesis nol diterima.Sehingga, diperoleh kesimpulan bahwa tidak ada hubungan yang signifikan antara dukungan keluarga terhadap pemberian ASI parsial.

Tabel 10. Hubungan Faktor Budaya terhadap Pemberian ASI Parsial

\begin{tabular}{lcccc}
\hline \multirow{2}{*}{ Faktor Budaya } & \multicolumn{2}{c}{ ASI Parsial } & \multirow{2}{*}{ Total } & p-value \\
\cline { 2 - 3 } & Ya & Tidak & & \\
\hline \multirow{2}{*}{ Mengikuti } & 24 & 13 & 37 & \\
\multirow{2}{*}{ Tidak Mengikuti } & $64,9 \%$ & $35,1 \%$ & $100 \%$ & \\
& $66,7 \%$ & $33,3 \%$ & $100 \%$ & 0,934 \\
Total & 28 & 15 & 43 & \\
& $65,1 \%$ & $34,9 \%$ & $100 \%$ & \\
\hline
\end{tabular}

Berdasarkan tabel 10, didapatkan hasil dari 43 responden yang mengikuti faktor budaya dengan pemberian ASI parsial sebanyak 24 responden $(64,9 \%)$ dan tidak melakukan pemberian ASI parsial adalah 13 responden (35,1\%). Responden yang tidak mengikuti faktor budaya dengan pemberian ASI parsial adalah 4 responden $(66,7 \%)$ serta tidak melakukan pemberian ASI parsial adalah 2 responden (33,3\%). 
Berdasarkan hasil uji Spearman rho yang diperoleh, menunjukkan nilai signifikansi $p$ value adalah 0,934 dimana derajat kemaknaan yang digunakan adalah $\alpha<0,05$ ( $p$-value $>0,05$ ). Hal ini menunjukkan bahwa hipotesis nol diterima. Sehingga, diperoleh kesimpulan bahwa tidak ada hubungan yang signifikan antara faktor budaya terhadap pemberian ASI parsial.

Tabel 11. Hubungan Pendidikan, Pengetahuan, Dukungan Keluarga, Faktor Budaya terhadap Pemberian ASI Parsial

\begin{tabular}{lcccccccc}
\hline & \multirow{2}{*}{ B } & S.E. & Wald & df & Sig. & \multirow{2}{*}{ Exp(B) } & \multicolumn{2}{c}{ 95\% C.I.for EXP(B) } \\
Lower & Upper \\
\hline Pendidikan & $-0,487$ & 0,512 & 0,908 & 1 & 0,341 & 0,614 & 0,225 & 1,674 \\
Pengetahuan & $-1,193$ & 0,703 & 2,885 & 1 & 0,089 & 0,303 & 0,077 & 1,202 \\
Dukungan Keluarga & 1,155 & 0,742 & 2,422 & 1 & 0,120 & 3,173 & 0,741 & 13,584 \\
Faktor Budaya & 0,556 & 1,158 & 0,230 & 1 & 0,631 & 1,743 & 0,180 & 16,872 \\
Constant & $-0,212$ & 1,753 & 0,015 & 1 & 0,904 & 0,809 & & \\
\hline
\end{tabular}

Berdasarkan hasil analisis multivariat tabel 11, diketahui bahwa dari semua variabel bebas, yaitu pendidikan, pengetahuan, dukungan keluarga, dan faktor budaya, semua nilai $p$ value-nya lebih besar dari 0,05 ( $p$-value $>0,05$ ). Responden dengan dukungan keluarga mendukung pemberian ASI parsial oleh keluarganya akan menyebabkan pemberian ASI parsial meningkat sebanyak 3,17 kali jika disandingkan dengan responden yang tidak memperoleh dukungan dalam memberikan ASI parsial oleh keluarganya.

\subsection{Pembahasan}

Berdasarkan hasil tabel 7 hubungan pendidikan dengan pemberian ASI parsial didapat hasil signifikansi ( $p$-value) adalah 0,134 dimana tingkat signifikansinya lebih besar dari 0,05 $(p$-value $>0,05)$. Hal tersebut membuktikan bahwa tidak ada hubungan yang signifikan antara tingkat pendidikan terhadap pemberian ASI parsial. Hal tersebut sesuai dengan penelitian yang dijalankan oleh Lestari, dkk, (2015), mengemukakan bahwa tidak ada hubungan yang signifikan antara pendidikan ibu dalam memberikan ASI parsial dimana nilai $p$-value yaitu 0,460 ( $p$-value $>0,05$ ). Walaupun pendidikan tinggi yang dimiliki oleh ibu dapat meningkatkan serta memudahkan dalam memahami pengetahuan yang diperoleh dan juga meningkatkan perilaku sehat namun, pemberian ASI parsial juga dapat dipengaruhi oleh faktor lain selain tingkat pendidikan, yaitu tradisi serta adat istiadat yang berkembang di masyarakat (Lestari, dkk., 2015). Pengetahuan yang dimiliki oleh ibu mengenai ASI parsial didapatkan melalui proses pada tingkat pendidikan baik itu secara formal maupun informal yaitu informasi yang diperoleh melalui brosur, penyuluhan yang diberikan oleh tenaga kesehatan, dan pemberian informasi baik secara langsung maupun tidak langsung oleh tenaga kesehatan dan pada saat melakukan kegiatan di Posyandu sehingga dapat mengarahkan ibu untuk dapat lebih bijak dalam memberikan ASI parsial (Khairani, Suryani, \& Roha, 2019).

Penelitian yang dijalankan oleh Darman, dkk, (2014) juga mendukung hal tersebut serta mengemukakan bahwa nilai signifikansi ( $p$-value) yang diperoleh dari hasil uji Chi-square adalah 1,00 dimana nilainya lebih besar dari 0,05 ( $p$-value $>0,05)$ sehingga diperoleh kesimpulan bahwa tidak ada hubungan yang signifikan antara tingkat pendidikan yang dimiliki ibu dengan pemberian ASI parsial (Darman, dkk., 2014). Pendidikan tinggi yang dimiliki oleh ibu akan menghasilkan pengetahuan yang baik pula sehingga, jika pengetahuannya baik akan memengaruhi perilaku seseorang dalam memberikan ASI secara eksklusif. Begitu juga 
sebaliknya, jika pendidikan yang dimiliki rendah akan memengaruhi pengetahuan yang dimiliki menjadi rendah pula sehingga, menyebabkan terjadinya perilaku yang kurang baik (Nurhayatia, Alit Armini, dan Kusumaningrum, 2020). Pendidikan tinggi dan rendah yang dimiliki dapat memberikan ASI parsial dibandingkan dengan ASI eksklusif. Hal ini dikarenakan perbedaan tingkat pendidikan tidak berbeda dalam perilaku pemberian ASI parsial kepada bayi (Juwita, Sitorus, dan Hanum, 2020).

Menurut asumsi peneliti, tingkat pendidikan tidak hanya memengaruhi pemberian ASI parsial, namun juga terdapat faktor lain yang memengaruhi pemberian ASI parsial kepada bayinya. Pendidikan rendah yang dimiliki oleh ibu dipengaruhi oleh pengetahuan yang mereka miliki. Tidak menutup kemungkinan ibu dengan pendidikan tinggi juga memberikan ASI parsial kepada bayinya.

Berdasarkan hasil tabel 8 hubungan pengetahuan terhadap pemberian ASI parsial diperoleh nilai $p$-value adalah 0,033 dimana nilainya lebih kecil dari 0,05 ( $p$-value $<0,05)$. Hal ini membuktikan bahwa ada hubungan yang bermakna antara pengetahuan terhadap pemberian ASI parsial. Hal ini selaras dengan penelitian yang dijalankan oleh Aldriana (2015), mengemukakan bahwa nilai $p$-value adalah 0,048 dimana nilainya lebih kecil dari 0,05 ( $p$-value $<0,05$ ) sehingga diperoleh kesimpulan bahwa ada hubungan yang signifikan antara tingkat pengetahuan yang dimiliki oleh ibu dengan pemberian ASI parsial. Rendahnya tingkat pengetahuan yang ibu miliki dalam memberikan makanan serta minuman tambahan dan waktu yang tepat dapat mengakibatkan pemberian ASI parsial sehingga akan menyebabkan tinggi dan cepatnya ASI yang diberikan oleh ibu kepada bayinya jika disandingkan dengan ibu yang memiliki tingkat pengetahuan baik. Tingkat pendidikan juga memengaruhi cara berfikir serta perilaku seseorang. Semakin tinggi pendidikan yang dimiliki, maka semakin mudah dalam memahami informasi sehingga pengetahuan dan wawasan akan lebih luas. Jika pengetahuan yang dimiliki baik, maka seseorang akan memberikan perlakuan yang tepat dalam memberikan makanan tambahan pada usia bayi 6 bulan dan diberikannya ASI secara eksklusif (Wulandari, Retnaningsih, dan Winarti, 2020).

Penelitian yang dijalankan oleh Haryanto (2017) juga mendukung hal tersebut serta mengemukakan bahwa ada hubungan yang signifikan antara tingkat pengetahuan dengan pemberian ASI parsial. Responden yang tingkat pengetahuannya baik menunjukkan bahwa mereka memahami jika bayi dengan usia di bawah 6 bulan sebaiknya tidak menerima makanan tambahan selain ASI yang dibutuhkan karena sistem pada pencernaannya yang belum sempurna untuk menerima makanan tambahan (Haryanto, 2017). Pemberian ASI parsial kepada bayi sebelum bayi berusia 6 bulan disebabkan oleh ibu yang terus berusaha untuk menjaga kebiasaan atau sikap adat istiadat yang sudah ada di masyarakat, seperti memberikan makanan berupa buah pisang yang dikerok, memberikan jamu, dan yang lainnya. Ibu dengan pengetahuan yang kurang baik akan memengaruhi dalam pemberian ASI parsial dimana makanan yang diberikan tidak tepat waktu dan tidak sesuai dengan usia bayi, sehingga akan memungkinkan kurang optimalnya dalam pemenuhan gizi serta dapat menimbulkan risiko kesehatan karena organ pencernaan bayi yang masih belum optimal (Mar'ati \& A'yun, 2021).

Menurut asumsi peneliti, walaupun ibu memiliki pengetahuan yang cukup, namun ibu juga dapat memberikan ASI parsial kepada bayinya. Hal ini bisa saja terjadi karena terdapat dorongan dari beberapa faktor lain yang turut memengaruhi dalam pemberian ASI parsial. Selain itu, tidak menjadi tolak ukur jika ibu dengan pengetahuan baik maupun cukup tidak 
akan memberikan ASI parsial kepada bayinya. Pengetahuan yang dimiliki memengaruhi sikap yang akan dilakukan. Saat pengetahuannya baik, hal tersebut tidak cukup untuk mendorong perilaku ibu dalam memberikan ASI dengan eksklusif sehingga ibu akan terdorong memberikan makanan tambahan serta susu formula bagi bayinya.

Berdasarkan hasil tabel 9 hubungan dukungan keluarga terhadap pemberian ASI parsial didapat nilai signifikansi ( $p$-value) yaitu 0,091, yang nilai signifikansinya lebih besar dari 0,05 ( $p$-value $>0,05$ ). Hal tersebut membuktikan bahwa tidak ada hubungan yang signifikan antara dukungan keluarga terhadap pemberian ASI parsial. Hal ini sesuai dengan penelitian yang dijalankan oleh Mayasari (2018), menyatakan bahwa nilai signifikansi ( $p$-value) yang diperoleh dari hasil uji Chi-square adalah adalah 0,735, dimana nilainya lebih besar dari 0,05 ( $p$-value $>0,05$ ) sehingga didapat kesimpulan tidak ada hubungan yang signifikan antara dukungan keluarga terhadap pemberian ASI parsial. Dukungan yang diberikan oleh keluarga bukan menjadi salah satu faktor dalam memberikan ASI parsial. Namun juga dapat disebabkan oleh faktor dari ibu sendiri karena beberapa ibu memiliki pekerjaan di luar rumah yang demikian akan menyebabkan ibu untuk memberikan makanan tambahan serta susu formula bagi bayinya dan akan mengurangi atau bahkan tidak memberikan ASI yang cukup hingga 6 bulan (Mayasari, 2018).

Penelitian yang dijalankan oleh Zuiatna dan Harahap (2019) mengemukakan hal yang berbanding terbalik dalam penelitiannya, yaitu nilai derajat kemaknaan ( $p$-value) adalah 0,019 dimana nilainya lebih kecil dari 0,05 ( $p$-value $<0,05)$ (Zuiatna dan Harahap, 2019). Sehingga diperoleh kesimpulan bahwa ada hubungan yang signifikan antara dukungan keluarga terhadap pemberian ASI parsial. Keluarga memiliki pengaruh dalam melakukan pemberian ASI parsial dikarenakan mereka beranggapan bahwa gizi yang dibutuhkan oleh bayi tidak akan terpenuhi, serta bayi akan merasa mudah lapar jika hanya diberikan ASI tanpa makanan atau susu formula tambahan (Maulidanita, 2020). Ibu dengan suami yang memberikan dukungan dalam pemberian ASI eksklusif selama 6 bulan kepada bayinya, maka pemberian makanan tambahan serta susu formula tidak akan terjadi (Oktarida, 2019).

Menurut asumsi peneliti, pemberian ASI parsial tidak dipengaruhi oleh dukungan keluarga. Hal ini dikarenakan beberapa ibu atau sebagian besarnya tidak didukung keluarga dalam memberikan ASI parsial dan sebagian lainnya tidak memberikan ASI parsial kepada bayinya. Tidak diberikannya dukungan dari keluarga dikarenakan keluarga sudah memiliki pemahaman mengenai manfaat dan pentingnya pemberian ASI secara eksklusif, serta dampak yang ditimbulkan jika diberikan ASI parsial.

Berdasarkan hasil tabel 10, hubungan faktor budaya terhadap pemberian ASI parsial didapat nilai $p$-value sebesar 0,934, yang nilai signifikansinya lebih besar dari 0,05 ( $p$-value > $0,05)$. Hal tersebut membuktikan bahwa tidak ada hubungan yang signifikan antara faktor budaya terhadap pemberian ASI parsial. Hal tersebut selaras dengan penelitian yang dijalankan oleh Winona \& Sari (2016), mengemukakan bahwa nilai derajat kemaknaan adalah 0,054 dimana nilainya lebih besar dari 0,05 ( $p$-value > 0,05), sehingga diperoleh kesimpulan bahwa tidak ada hubungan yang signifikan antara budaya dengan pemberian ASI parsial. Faktor budaya tidak memengaruhi pemberian ASI parsial dikarenakan ibu-ibu yang sudah mulai kritis dalam mencari informasi mengenai waktu yang tepat dalam memberikan makanan tambahan serta pentingnya dalam pemberian ASI secara eksklusif oleh ibu kepada bayinya (Winona \& Sari, 2016). 
Penelitian yang dijalankan Kumalasari, dkk, (2015) juga mendukung hal tersebut serta mengemukakan bahwa hasil signifikansi ( $p$-value) adalah 0,141, dimana nilainya lebih besar dari 0,05 ( $p$-value $>0,05$ ). Sehingga, diperoleh kesimpulan bahwa tidak ada hubungan yang signifikan antara budaya dengan pemberian ASI parsial. Pemberian ASI parsial berupa makanan tambahan serta susu formula saat bayi berusia dibawah 6 bulan disebabkan oleh kebiasaan perilaku dan sikap ibu dalam memberikan ASI parsial yang sudah diturunkan dari orangtua ibu dengan memberikan makanan bagi bayi berupa bubur nasi dan bubur pisang yang dilakukan saat acara aqiqah (Kumalasari, dkk., 2015). Selain itu, terdapat beberapa ibu yang beranggapan bahwa kolostrum yang telah diproduksi tidak memiliki nilai gizi yang baik dan juga mengatakan bahwa kolostrum adalah ASI yang kotor yang tidak dapat dicerna dan jika bayi mereka akan merasakan sakit perut jika meminum kolostrum (Hassan, Kishoyian, \& Orinda, 2015). Bayi yang diberikan ASI parsial oleh ibunya dikarenakan ibu menganggap jika pemberian makanan tambahan dan susu formula merupakan salah satu solusi dalam mengatasi kurangnya pemberian ASI oleh ibu maupun ibu yang tidak cukup dalam memproduksi ASI. Selain itu, anggapan bahwa pertumbuhan bayi yang lambat dan pengalaman yang dimiliki ibu setelah memberikan susu formula dan makanan tambahan kepada anak-anak sebelumnya (Leli \& Samsiana, 2021).

Menurut asumsi peneliti, faktor budaya tidak memengaruhi pemberian ASI parsial. Hal ini dikarenakan walaupun sebagian besar ibu mengikuti budaya setempat dan memberikan ASI parsial, tetapi sebagian lainnya tidak memberikan ASI parsial kepada bayinya. Walaupun masyarakat mengikuti budaya setempat, namun tidak memengaruhi ibu untuk memberikan makanan dan minuman tambahan atau ASI parsial kepada bayinya. Hal tersebut menunjukkan bahwa kebudayaan tinggi yang beredar di masyarakat, tidak dengan mudah memengaruhi perilaku yang dilakukan oleh ibu dalam memberikan ASI parsial.

Berdasarkan hasil tabel 11, diperoleh hasil bahwa tidak ada hubungan yang signifikan antara tingkat pendidikan, tingkat pengetahuan, dukungan keluarga, serta faktor budaya terhadap pemberian ASI parsial. Sesuai dengan penelitian yang telah dijalankan oleh Septiani (2014) membuktikan bahwa pendidikan yang rendah dapat memengaruhi ibu dalam memberikan ASI parsial dikarenakan ibu tidak mengetahui waktu serta makanan yang tepat untuk diberikan kepada bayinya (Septiani, 2014). Ibu dengan pengetahuan baik dapat memberikan susu formula dikarenakan ibu yang tertarik terhadap iklan promosi yang ditampilkan di televisi mengenai produk-produk susu formula menjadikan ibu mudah terpengaruhi dan memberikan susu tersebut kepada bayinya (Nuraini, Nusri, \& Pebryani, 2018).

\section{Simpulan}

Menurut analisis yang telah dijalankan oleh peneliti, maka diperoleh kesimpulan yaitu tidak ada hubungan yang signifikan antara pendidikan terhadap pemberian ASI parsial di Kota Malang, ada hubungan yang signifikan antara tingkat pengetahuan yang dimiliki oleh ibu terhadap pemberian ASI parsial di Kota Malang, tidak ada hubungan yang signifikan antara dukungan yang diberikan oleh keluarga kepada ibu terhadap pemberian ASI parsial di Kota Malang, tidak ada hubungan yang signifikan antara faktor budaya yang berada di masyarakat terhadap pemberian ASI parsial kepada ibu di Kota Malang. 


\section{Daftar Rujukan}

Aldriana, N. (2015). Faktor-Faktor yang Berhubungan dengan Pemberian MP-ASI Dini di Desa 2 Dayo Wilayah Kerja Puskesmas Tandun II Kabupaten Rokan Hulu Tahun 2013. Jurnal Maternity and Neonatal, 2(1), 1-9. http://e-journal.upp.ac.id/index.php/akbd/article/download/1085/7862

Arsyati, A. M., \& Rahayu, Y. T. (2019). Budaya Pemberian Makanan Pendamping Asi (Mp-Asi) pada Bayi Usia Kurang Dari 6 Bulan di Desa Leuwibatu Rumpin. Hearty Jurnal Kesehatan Masyarakat, 7(1), 9-17. https://doi.org/10.32832/hearty.v7i1.2297

Darman, S., Fanny, L., Suaib, F., \& Nadimin. (2014). Hubungan Pendidikan, Pengetahuan dan Pekerjaan Ibu dengan Pemberian MP-ASI Dini di Desa Bonto Marannu. Jurnal Media Gizi Pangan, XVIII(2), 31-37.

Dinas Kesehatan Provinsi Jawa Timur. (2020). Profil Kesehatan Provinsi Jawa Timur. Profil Kesehatan Provinsi Jawa Timur, 25-26.

Haryanto, E. (2017). Faktor-Faktor yang Berhubungan dengan Pemberian Makanan Pendamping ASI Dini. Jurnal Aisyah : Jurnal Ilmu Kesehatan, 2(2), 141-152.

Hassan, M. A., Kishoyian, G. M., \& Orinda, G. O. (2015). Determinants of Early Weaning of Infants Below Six Months Among Lactating Mothers at Wajir County Referral Hospital. Internasional Journal of Sciences: Basic and Applied Research, 4531, 119-131.

Juwita, Z., Sitorus, S., \& Hanum, R. (2020). Factors Related to Giving MPASI in Babies Aged 0-6 Months in the Region Mongeudong Health Center Work Sub-District Banda Sakti Lhokseumawe. Journal La Medihealtico, 1(5), 40-53. https://doi.org/10.37899/journallamedihealtico.v1i5.151

Kemenkes RI. Pusat Data dan Informasi Situasi dan Analisis ASI Eksklusif. (2014). Kementrian Kesehatan Replubik Indonesia. Kementerian Kesehatan Republik Indonesia.

Kementerian Kesehatan Republik Indonesia. (2019). Profil Kesehatan Indonesia. In Kementerian Kesehatan Republik Indonesia. https://doi.org/10.5005/jp/books/11257_5

Kementerian Kesehatan Republik Indonesia Provinsi Jawa Timur. (2018). Hasil Utama Riset Kesehatan Dasar Jawa Timur 2018. Badan Penelitian Dan Pengembangan Kesehatan, Kementrian Kesehatan Republik Indonesia, 1-82.

Kementerian Kesehatan RI Badan Penelitian dan Pengembangan. (2018). Hasil Utama Riset Kesehatan Dasar. Kementrian Kesehatan Republik Indonesia, 1-100. https://doi.org/1 Desember 2013

Khairani, N., Suryani, \& Roha, A. D. (2019). Hubungan Pendidikan dan Pengetahuan dengan Pemberian MP-ASI Dini di Posyandu Baruna 3 Wilayah Kerja Puskesmas Padang Serai Kota Bengkulu. CHMK Nursing Scientific Journal, 3(1), 1-8.

Kumalasari, S. Y., Sabrian, F., \& Hasanah, O. (2015). Faktor-faktor yang berhubungan dengan pemberian Makanan pendamping ASI dini. Jurnal Online Mahasiswa (JOM) Bidang Ilmu Keperawatan, 2(1), 879889.

Leli, L. (2021). Pengaruh Sosial BudayaTerhadap Pemberian MP-ASI Dini di Wilayah Kerja UPTD Puskesmas Moncongloe. Afiasi: Jurnal Kesehatan Masyarakat, 6(1), 45-53.

Lestari, E., Widiastuti, Y. P., Kunsianah, \& Qomariyah, N. (2015). Faktor-Faktor yang Mempengaruhi Perilaku Ibu dalam Pemberian MP-ASI Dini di Desa Jungsemi Kecamatan Kangkung Kabupaten Kendal. Keperawatan, 215-221.

Mar'ati, R., \& A'yun, Q. (2021). Hubungan Pengetahuan Ibu dengan Pemberian MP-ASI pada Bayi Usia 0-6 Bulan di Polindes Billa'an Kecamatan Proppo Kabupaten Pamekasan. Jurnal Sakti Bidadari, IV(1), 12-19.

Mardhani, R. P. P. K. (2019). Hubungan Faktor Lingkungan Fisik Rumah, Status Pendidikan Ibu, dan Status Pekerjaan Ibu Terhadap Kejadian Pneumonia Balita di Wilayah Kerja Puskesmas. Jurnal Sport Science And Health, 1(3), 233-242.

Maulidanita, R. (2020). Faktor yang Berhubungan Dengan Pemberian Makanan Pendamping Air Susu Ibu pada Bayi 0-6 Bulan Di BPM Romauli Silalahi. Jurnal Kesehatan, 3(2), 123-131.

Mayasari, E. (2018). Faktor-Faktor yang Berhubungan dengan Pemberian MP-Asi Secara Dini di Kelurahan Bagan Jawa Pesisir Wilayah Kerja Puskesmas Bagan Siapiapi Kecamatan Bangko Kabupaten Rokan Hilir. Doppler, 2(2), 21-28.

Nuraini, S., Nusri, M. T., \& Pebriani, U. (2018). Hubungan Pengetahuan Ibu Terhadap Perilaku Pemberian Makanan Pendamping Asi (Mp-Asi) Pada Bayi Usia 0-6 Bulan Di Posyandu .... Jurnal Ilmu Kedokteran ..., 5(1), 51-59. http://ejurnalmalahayati.ac.id/index.php/kesehatan/article/download/787/729 
Nurhayatia, M. A., Alit Armini, N. K., \& Kusumaningrum, T. (2020). Analysis of Breastfeeding Factors: The Sunrise Model Approach. Medico-Legal Update, 20(1), 334-339. https://doi.org/10.37506/v20/i1/2020/mlu/194347

Oktarida, Y. (2019). Faktor Penyebab Yang Berhubungan Dengan Pemberian MP-ASI pada Bayi Usia 0-6 Bulan di UPTD Puskesmas Kemalaraja Kabupaten Oku. JKSP, 2(1), 71-76.

Putri, R., \& Illahi, S. A. (2017). Hubungan Pola Menyusui dengan Frekuensi Kejadian Sakit pada Bayi. Journal of Issues in Midwifery, 1(1), 30-41.

Rosita, E., \& Imrohwati, D. (2016). Hubungan Tingkat Pendidikan Ibu dengan Pemberian MP-ASI Dini pada Bayi Usia 0-6 Bulan (Studi di UPT Puskesmas Kemlagi Kecamatan Kemlagi Kabupaten Mojokerto Provinsi Jawa Timur). Midwifery Journal of STIKes Insan Cendekia Medika Jombang, 11(1), 11-15. https://doi.org/10.1017/CB09781107415324.004

Septiani, W. (2014). Hubungan Pemberian Makanan Pendamping Asi Dini dengan Status Gizi Bayi 0-11 Bulan di Puskesmas Bangko Rokan Hilir. Jurnal Kesehatan Komunitas, 2(4), 148-153. https://doi.org/10.25311/jkk.vol2.iss4.63

Sihombing, S. (2018). Hubungan Pekerjaan dan Pendidikan Ibu dengan Pemberian Asi Ekslusif di Wilayah Kerja Puskesmas Hinai Kiri Tahun 2017. Midwifery Journal, 5(01), 40-45.

Virtanen, S. M., Uusitalo, L., \& Knip, M. (2013). Early Introduction of Complementary Foods: is There a Link with Type 1 Diabetes? Diabetes Management, 3(1), 53-59. https://doi.org/10.2217/dmt.12.55

Widiyoga, C. R., Saichudin, \& Andiana, O. (2020). Hubungan Tingkat Pengetahuan tentang Penyakit Diabetes Melitus pada Penderita terhadap Pengaturan Pola Makan dan Physical Activity. Sport Science Health, 2(2), 152-161.

Winona, L., \& Sari, F. (2016). Pemberian Makanan Pendamping Air Susu Ibu (MP-ASI) Dini pada Bayi Usia 0-6 Bulan di BPM N Jakarta Selatan tahun 2016. Jurnal Bidang Ilmu Kesehatan, 2(8), 495-499. https://doi.org/10.1017/CB09781107415324.004

Wulandari, P., Retnaningsih, D., \& Winarti, R. (2020). Hubungan Pengetahuan Dengan Pemberian Mp-Asi Dini Pada Ibu Yang Mempunyai Bayi Usia 0-6 Bulan. Jurnal Keperawatan, 12(2), 223-230. http://journal.stikeskendal.ac.id/index.php/Keperawatan/article/view/739

Yanthi, N. K. R. E., \& Masruroh. (2018). Pengetahuan dan Pekerjaan Ibu Berhubungan dengan Pemberian MPASI Dini di Desa Ngampin Wilayah Kerja Puskesmas Ambarawa. Siklus : Journal Research Midwifery Politeknik Tegal, 7(2), 315-323. https://doi.org/10.30591/SIKLUS.V7I2.844.G743

Zuiatna, D., \& Harahap, N. R. (2019). Pengaruh Faktor Eksternal Ibu Terhadap Pemberian MP-ASI pada Bayi Usia Dibawah 6 Bulan di Wilayah Kerja Puskesmas Sipori-Pori Kota Tanjung Balai. Nursing Arts, XIII(02), 87-97. 